\section{HISTORY OF GEOLOGY IN GREAT BRITAIN}

\section{Geological Survey of Great Britain}

By Sir Edward Bailey. Pp. xii $+278+4$ plates. (London: Thomas Murby and Co., 1952.) 22s.6d.net.

$\mathrm{T}$

HIS account of the history of the Geological Survey of Great Britain, written by a former director of the Survoy, is a noteworthy publication. Although it follows a centenary volume by one of his predecessors published still far short of twenty years ago, it will not surprise those who have known both authors that the two books differ in many respects. The present volume is one that should find a place in every geological library, and it is worthy to be added to books devoted to the history of the subject.

The Geological Survey is the oldest organization of its kind in the world, dating its institution from 1835 ; there was, of course, official but discontinuous geological mapping before that date in Great Britain and elsewhere. The Survey has been token as a pattern for the organization of similar work by many countries. This book contains an account of the problems met with through this long history, and of the ways in which they have been dealt with. Each chapter (though they are not called by that name) deals with the work of one of the successive directors and with his more important achievements and difficulties. Alongside this history of Survey activities, there is some account, especially in the earlier years, of the development of geological ideas both in the Survey and outside. To the student this volume will thus supply a valuable introduction to the history of the science as a whole. As the Geological Survey grew, there was a considerable degree of similarity between the development of ideas among its members and of those who were not attached to its staff. The numbers of those geologists engaged in the Survey and in the universitios have always been smallsmaller than those in most sciences-and, leaving aside the very important band of amateurs whose contribution to some fields of geology have been outstanding, the Survey has held on an average about one-half of the employed geologists in Britain. It is not surprising, therefore, to find that in many ways its history is to a great extent the history of British geology.

The Geological Survey was founded in order to expedite the provision of one-inch maps with geological boundaries, and the production of such maps (each with an accompanying memoir containing a description of the geology of the area which is summarized on the map) has continued to be one of the Survey's most important tasks. Several diagrams show very cleaxly the progress towards this objective. But with greater demands the work became slowed down very considerably, even so long as seventy or eighty years ago. Thus the reader is shown on p. 84 how the rate of completion of English one-inch maps became less than half as rapid under Ramsay as it had been in a corresponding period under his predecessor Murchison. The rate rose again with the next director, Archibald Geikie, to exceed that reached under Murchison. This variation is partly accounted for by the use made of six-inch maps as a basis of surveying. This was officially ended by Geikie in the 'eighties, though it had been in existence for some twenty years.

Geikie was anxious to complete the geological mapping of Great Britain, having more or less under- taken on his appointment "to wind up most of the activities of his office". How many since that time have demanded to know how long it would be before the primary task of the Survey was accomplished? All one can now say, unless there is a large expansion in numbers, with the demand for greater detail and for the need for frequent revision (at least in some areas), is that the geological survey will never be complete, for new tasks are added more rapidly than they can be overtaken. Geikie would find an organization much larger than in his day, but with its responsibilities continually expanding.

So many topics are discussed in this volume, especially in those sections relating to later years, that a reviewer can only indicate the wide range of problems. The linkage with other government services is traced from the days when the Geological Survey was one of the very few scientific bodies established under the Government (many may read with amazement that in 1871 a director's funeral was joined by royal carriages and that a Prime Minister followed the bier), to its present position as one of the divisions since 1919 of the Department of Scientific and Industrial Research. The glimpse of the Geological Survey's relation to water-divining, or dowsing, in the Second World War is one of the many reminders of present activities.

Altogether this is a book from which few will not be able to learn. Other writers would perhaps have chosen differently, but with so much available, particularly of recent history, the author must make some selection. Little of importance appears to have escaped his notice, however. The book is illustrated with plates and line-drawings, many of the latter reproduced from memoirs of dates ranging from near its foundation until more than a century later and illustrating some of the more important conclusions reached in that time.

A. E. Trueman

\section{ANCIENT EGYPT}

\section{Ancient Egypt}

By J. E. Manchip White. Pp. xii $+217+48$ plates. (London: Allan Wingate (Publishers), Ltd., 1952.) 21s. net.

$7 \mathrm{HE}$ history of Egypt is unlike that of any other country in the world. For centuries, indeed for millennia, geography imposed so complete an isolation on the region that the evolution of Egyptian calture, especially that of Upper Egypt, became rigidly circumscribed and unaffected by influences from the outside world. The thought of the people throughout centuries of existence seems to have been conditioned by their peculiar natural environment, canalized, almost solidified, and but little influenced by ideas germinated in other civilizations. It is true that, during periods of exceptional governmental weakness, invasions of foreigners did take place; but their effect seems not to have been permanent, and when the central authority once again became strong the invaders were turned out. Perhaps the Biblical account of the ejection of Adam and Eve from Eden is a poetical remembrance of the ejection of the Shepherd Kings from the Nile Delta.

Only when Egypt under the kings of the Eighteenth Dynasty tried to found an empire in Nearer Asia, and for a time succeeded, were the seeds of future final decadence sown. From then onwards, in spite of brilliant flashes of returning vitality, the end 